\title{
Determinants of multimedia, entertainment, and business software copyright piracy: a cross-national study
}

Citation for published version (APA):

van Kranenburg, H. L., \& Hogenbirk, A. E. (2003). Determinants of multimedia, entertainment, and business software copyright piracy: a cross-national study. METEOR, Maastricht University School of Business and Economics. METEOR Research Memorandum No. 020 https://doi.org/10.26481/umamet.2003020

Document status and date:

Published: 01/01/2003

DOI:

10.26481/umamet.2003020

Document Version:

Publisher's PDF, also known as Version of record

Please check the document version of this publication:

- A submitted manuscript is the version of the article upon submission and before peer-review. There can be important differences between the submitted version and the official published version of record.

People interested in the research are advised to contact the author for the final version of the publication, or visit the DOI to the publisher's website.

- The final author version and the galley proof are versions of the publication after peer review.

- The final published version features the final layout of the paper including the volume, issue and page numbers.

Link to publication

\footnotetext{
General rights rights.

- You may freely distribute the URL identifying the publication in the public portal. please follow below link for the End User Agreement:

www.umlib.nl/taverne-license

Take down policy

If you believe that this document breaches copyright please contact us at:

repository@maastrichtuniversity.nl

providing details and we will investigate your claim.
}

Copyright and moral rights for the publications made accessible in the public portal are retained by the authors and/or other copyright owners and it is a condition of accessing publications that users recognise and abide by the legal requirements associated with these

- Users may download and print one copy of any publication from the public portal for the purpose of private study or research.

- You may not further distribute the material or use it for any profit-making activity or commercial gain

If the publication is distributed under the terms of Article $25 \mathrm{fa}$ of the Dutch Copyright Act, indicated by the "Taverne" license above, 


\title{
Determinants of Multimedia, Entertainment, and Business Software Copyright Piracy: A Cross-national Study
}

\author{
By \\ H.L. (Hans) van Kranenburg *, ** \\ and \\ A.E. (Annelies) Hogenbirk \\ *Corresponding Address \\ University of Maastricht \\ Faculty of Economics and Business Administration \\ Department of Organization and Strategy \\ P.O. Box 616 \\ 6200 MD Maastricht \\ The Netherlands \\ e-mail: H.vankranenburg@,OS.unimaas.nl
}

Research Memorandum RM/03/020

Maastricht, May 2003

Keywords: Intellectual property protection, multimedia industries, economy wide country

study

** This paper has been presented at $5^{\text {th }}$ World Media Conference in Turku in 2002 and the 2002 AIB Annual Meeting in Puerto Rico. The authors are grateful for useful comments by the participants at these conferences and the referees. 


\title{
Determinants of Multimedia, Entertainment, and Business \\ Software Copyright Piracy: A Cross-national Study
}

\begin{abstract}
This paper examines cross-national variations in piracy of U.S. copyright related products in the multimedia, entertainment, and software industry. To determine which economic, legal, and social factors cause the considerable differences in piracy of U.S. copyright industries' products in individual countries, we tested 4 industry models. We find that for most industries piracy can be explained by the risk profile of the country involved (signalling economic and political stability and growth potential) and the existence of a strong intellectual property rights system. Furthermore, for the four analysed copyright-based industries considerable variation in piracy exists between geographic regions. This study shows that disaggregation of the copyright piracy data by industry is helpful in analysing and understanding piracy.
\end{abstract}




\section{Introduction}

Copyright piracy has become a major issue in trade negotiations - for example within the World Trade Organization - and in the strategies of entertainment, multimedia, and software companies. Copyright piracy not only affects the economic position of these companies, but it may also influence the development of many national economies (Husted, 2000). Industrialized countries emphasize the need to increase the protection offered to property rights for creative products. Samuelson (1999) and Stegemann (2000) mentioned that in particular US companies with strong copyright interests and their partners are shaping the intellectual-property-related trade diplomacy of the United States in the World Trade Organization. These companies have vigorously argued that inadequate copyright protection would threaten the basic incentive of copyrights and would jeopardize investments in the creation and innovation of products in business, literature, music, arts, and science (Samuelson, 1996; Stolpe, 2000). The companies in the copyright-based industries have in common that their products could be imitated and copied at a relatively low cost (Gallegos, 1999; Stolpe, 2000). The International Intellectual Property Alliance (IIPA), a coalition consisting of seven U.S. copyright industry representative trade associations established in 1984, estimated that the revenue losses due to illegal copying experienced by the U.S. copyright-based entertainment and multimedia industries are more than eight billion US dollars every year (IIPA, 2000). The copyright-dependent industries therefore emphasize the importance of strengthening the protection of intellectual property rights internationally and promote the cross-border harmonization of intellectual property rights regimes (Singer, Calton, and Singer, 2001). Although there is considerable concern among governments and companies about the impact and consequences of copyright piracy and protection in the creative industries, the literature discussing these issues is ambiguous. 
Economists, politicians, legal scholars, and other professionals related to creative industries are still debating the effects of unauthorized copying on society and companies and the need to prevent illegal activities. A large group of studies are concerned with the influence that strengthening the protection of intellectual property rights will have on society. In this context, researchers have considered the social and economic developments of an economy under various enforcement and protection systems. For instance, on the one hand, Gould and Gruben (1996) found that intellectual property rights foster the economic growth of a society. On the other hand, several other studies found that in particular southern countries have little incentive to protect the property rights of industrialized countries but rather allow piracy to stimulate their economy (Deardorff, 1992, 1995; Yang, 1998; Markussen, 2001). Dunning (1993), Seyoum (1996) and Mille (1997) showed that the protection of intellectual property rights is positively related to rates of foreign direct investments and innovations in a country. At the same time, the diffusion and adoption of a new technology can also be speeded up when intellectual property protection is weaker. A rapid diffusion of knowledge spurs complementary and cumulative innovations that result in a rapid adoption of and large demand for a new technology (Burke, 2000; Tang and Tunzelmann, 2000). The evidence regarding the effect of intellectual property rights protection on society is therefore inconclusive.

Another group of studies examines the strategic behavior of companies and the impact of unauthorized copying of their products on their performance. Again the findings are ambiguous. Studies by for instance IIPA (2000), Gallegos (1999) and Simon (1996) emphasized that piracy is harmful to companies in copyright-based industries. As a result of piracy, companies lose sales and receive lower revenues. Furthermore, by not knowing the users of pirated products, companies also lose opportunities to cross-sell their other products and capitalize on any ideas from illegal users for improving the product or developing new 
products (Givon, Mahajan and Muller, 1995). However, other studies did not confirm these findings. A company's most profitable strategy may indeed be to encourage imitation when the size of the user base influences the perceived quality of the product (e.g. Liebowitz, 1985; Conner and Rumelt, 1991; Takeyama, 1994; Conner, 1995). The company then experiences positive consumption or network externalities due to piracy because it results in an increase in the number of individuals using the product (e.g. Katz and Shapiro, 1985, 1986; Takeyama, 1997; Shy and Thisse, 1999).

For decisions on strategic positioning, exports, and foreign direct investment behavior, copyright-based firms need to know what types of countries provide strong copyright protection. Although the US are most strongly insisting on higher protection standards in developing countries (Markusen 2001), there appear to be considerable differences in piracy rates between industries and countries. Even industrialized countries show substantial differences in piracy (Gallegos, 1999; Husted, 2000; Legrand 1998).

Surprisingly little is known about how intellectual property rights protection is actually determined and which economic, legal, and social factors contribute to this protection. Studying the determinants of copyright piracy rates and the estimated companies' revenue losses suffered abroad due to piracy would be useful for understanding the strategy and policy initiatives to be undertaken by the copyright-based industries and the governments. This current study extends existing studies by examining the cross-national variation in piracy in four US copyright-based industries: business software applications, record and musical compositions, motion pictures, and entertainment software (e.g. Burke, 1996; Husted, 2000; Marron and Steel, 2000). We not only look at piracy rates, but also at the estimations of the revenue losses suffered by the creative industries resulting from piracy of their products abroad. $^{\mathrm{i}}$ We concentrate on the US because of its size in copyright related products and the availability of data. Therefore first the core US copyright-based industries are introduced. 
After that we discuss the extent of piracy in several countries. The next section develops a conceptual framework and hypotheses that explain the differences across countries in piracy rates and revenue losses. The following section presents the data. Then we show the econometric findings in order to determine which of the hypotheses are supported, followed by a discussion of the findings. Finally, conclusions are drawn in the last section.

\section{The US copyright industries}

The US core copyright-based industries broadly comprise of eight industries: motion pictures (television, theatrical, and home video); recording (records, tapes, and CDs); music publishing; computer software applications (both for business and entertainment); books, journals, and newspaper publishing; radio, television, and cable broadcasting; legitimate theater; and advertising (IIAP, 2001). These industries create copyrighted works as their primary product. The economic contribution of these industries to the US economy is substantial. Siwek (2000) showed that those core copyright-based industries accounted for 4.9 percent of U.S. GDP in 1999, and that in the last two decades their share in GDP grew twice as fast annually as the remainder of the economy. Currently, 3.24 percent of all US employees find work in these industries, amounting to 4.3 million workers. The international market for copyright protected materials has shown considerable growth. Therefore, the copyright-based industries' foreign sales and exports (estimated to be at least 79.65 billion US dollars in 1999) continue to be larger than the exports of almost all other U.S. leading industries, such as chemicals and allied products, automobiles, aircraft, and agriculture (IIPA, 2001). However, the most important weakness of these creative industries relates to the ease with which their products can be (illegally) copied and sold. Recently, the increase in copying related innovations has further facilitated piracy and as a consequence may have a negative effect on the financial results of the creative companies. 


\section{A Worldwide Piracy Problem}

These developments have prompted a desire for international copyright legislation. As part of the IIPA efforts to protect the US copyright-based industries, it annually reports the deficiencies of the copyright regimes of countries where the U.S. copyright-based industries suffered the most ${ }^{\mathrm{ii}}$. These countries are ranked on the Special 301 lists according to the importance of monitoring their intellectual property practices by the US (IIPA, 1998, 1999, 2000, 2001).

-Insert Table 1 about here

Table 1 presents a summary of the estimated piracy rates for four creative industries in different countries for the year 1999: motion pictures; sound recording and musical compositions; business software applications, and entertainment software ${ }^{\mathrm{iii}}$. Appendix A describes the construction of the piracy data for these four US copyright-based industries. As shown by the standard deviation values and the range values in this table, the piracy rates for a particular creative industry vary substantially between countries. In some countries, virtually all motion pictures have been pirated. Vietnam, Costa Rica, Bolivia, and Latvia, for example, had piracy rates of $95 \%$ or more in 1999 . Other countries, for instance, Greece, Korea, and Italy, had piracy rates in these materials below $25 \%$. However, looking at the business software applications piracy rate then Greece no longer has the lowest rate but is positioned somewhere in the middle. Now the Czech Republic (42\%), Israel (44\%), and Italy (44\%) have the lowest piracy rates, while China (91\%), the Russian Federation (89\%) and Vietnam (98\%) have the highest. The average entertainment software piracy rate is more than $78 \%$ for the monitored countries. The lowest rank country is El Salvador with a piracy rate of $50 \%$ for entertainment software materials. Malaysia (99\%) and the former Soviet Union members 
(95\% or more) are top-rank countries when it comes to piracy in this industry. The average sound recording and musical compositions piracy rate of the countries listed in the 301 Report is approximately $50 \%$ but the standard deviation is high, with rates ranging from $8 \%$ for Czech Republic to 95\% for Brazil and Ukraine.

Although the piracy rates differ significantly within and between countries for these four industries, they give insufficient information to draw conclusions on the economic effects of unauthorized production and distribution of materials for personal and/or business purposes. We need to understand the revenue losses suffered by the US copyright-based companies to fully comprehend the economic effect caused by illegal copying. IIPA also reports estimates of these losses. These data have to be carefully interpreted because they may overestimate the incurred loss. Firstly, loss revenue is usually estimated by multiplying the legitimate price of the product by the estimated number of pirated copies. However, many of these copies would not have been purchased at the legitimate price (Marron and Steel, 2000). Secondly, companies may also experience positive network externalities due to piracy resulting from an increase in the critical mass. Given that no other data are available, these estimates currently provide the best insights in the financial consequences of piracy for the creative industries.

There exists a very weak relationship between the estimated dollar revenue losses suffered by the US copyright-based industries in foreign countries and the piracy rates. The average correlation between piracy rates and associated revenue losses is only 0.15 and statistically not significantly different from zero. It is therefore possible that considerable revenue losses suffered by US creative companies due to piracy occur in countries that have low piracy rates. To fully understand the total impact of piracy it is necessary to compare the estimates of the revenue losses in each country as well as the piracy rates for each industry abroad. The average estimated revenue losses abroad for the four US creative industries are reported in table 2 . 
-Insert Table 2 about here

We see that the largest revenue losses occur in the software industries. The entertainment software industry both has the highest mean and the highest standard deviation, signaling considerable revenue losses for US firms. According to IIPA (2001), the estimated worldwide total revenue loss for this US industry amounts to at least 2.9 billion US dollars. China creates the highest revenue loss for the entertainment software companies amounting to almost 1.4 billion US dollars, while countries such as El Salvador and Guatemala show the lowest revenue losses ( 0.1 million US dollars). Furthermore, the estimated revenue losses suffered by US creative companies caused by unauthorized production and distribution of the business software applications is also the highest in China (437.20 million US dollars), although now closely followed by Italy (338.40 million US dollars) and Brazil (319.30 million US dollars). The lowest ranked country is Lebanon with a counterfeiting revenue loss of only 1.6 million US dollars. However, looking at the sound recording and musical compositions revenue losses then Brazil shows the highest unauthorized copyright production of 300 million US dollars. In contrast, other countries, for instance Oman, Qatar, and Jordan, created revenue losses for US companies in these materials below 1 million US dollars. The estimated average US motion pictures counterfeiting revenue loss in the countries listed in the 301 Report is approximately 29 million US dollars with the levels ranging from 0.5 million for Qatar to 250 million US dollars for the Russian Federation.

\section{Conceptual framework and hypotheses}

Only recently, economists and policy analysts have begun to explore the determinants of intellectual property rights protection and violation. The studies take into account the different 
contexts within which piracy occurs. Most studies investigated the patent-related industries and the business software applications industry. Few studies explore the differences in other creative industries' piracy rates or estimated revenue losses at the country level. This paper tries to fill this gap. As a starting point for this study we use the findings of various works that investigate the cross-national differences of piracy in the copyright-based industries, contributing these differences to a country's specific social, legal, and economic factors. The existing literature on the determinants of intellectual property rights violation can be summarized in the following conceptual framework (figure 1).

Insert Figure 1 about here

Broadly speaking four groups of variables influence the levels of piracy and the intellectual property rights protection in a country. First of all, many studies have investigated the relationship between a country's economic situation and the intellectual property rights (in particular patent) protection. These studies include, among others, Rapp and Rozek (1990), Mansfield (1994), Ginarte and Park (1997), Maskus (1998), and Marron and Steel (2000). The literature indicates a relationship between market size and intellectual property rights protection. Large markets, in general, are attractive locations for inward foreign direct investments (Buckley and Casson, 1981). However, foreign direct investments are not attracted to places with weak intellectual property rights protection (Dunning, 1993; Lee and Mansfield, 1996; Seyoum, 1996). Furthermore, large markets also contain more opportunities for piracy, given that the identification of the unauthorized producers and users of the illegal products is more difficult than in smaller markets (Tang and Tunzelmann, 2000). In a large market even piracy at a small scale can create a considerable loss for the creative firms. To protect their businesses, these companies put pressure on host country governments to 
strengthen the protection of intellectual property rights (Samuelson, 1999). They may retaliate with actions such as trade impediments, to ensure protection from piracy. This threat of retaliation increases with the size of the host market (Stegemann, 2000). Many larger countries therefore try to reduce the unauthorized production and use of intellectual property rights-related products. To examine the relationship between market size and piracy rates and revenue losses suffered by foreign copyright-based industries in a country, we suggest the following two hypotheses:

Hypothesis 1a: The larger the market size of a host country, the lower the piracy rates of copyright-based products.

Hypothesis 1b: The larger the market size of a host country, the higher the revenue losses suffered by foreign copyright-based industries.

Furthermore, the overall level of economic development also influences the intellectual property rights protection. Burke (1996) and Marron and Steel (2000), for instance, indicate that the higher the level of economic development, the less likely that piracy occurs. This is also confirmed by Silva and Ramello (2000) who found strong evidence of the presence of a buoyant market of unauthorized reproduction of sound recording products in emerging and less developed regions. Similar results are found in studies focusing on the influence of social and economic conditions and the strength of economic institutions on software piracy. Marron and Steel (2000) found that countries with strong institutions protecting contracts and property also tend to have lower piracy rates. In general, countries that make inefficient public investments and economic policy decisions do not have protection systems or have weak ones (Knack and Keefer, 1995). Ginarte and Park (1997) emphasize that indicators of political 
credibility and economic development, such as market freedom and openness, are important determinants of the provision of property rights.

The level of economic and social development, political credibility, and the security of legal rights are reflected in measurements of country risk (Oetzal, Bettis, and Zenner, 2001). The country risk measure determines the effect of possible political or economic events on the business climate in a country. Companies may experience less protection of the intellectual property rights in countries that are characterized by high risk, and are therefore likely to suffer considerable revenue losses. Moreover, the security of property and contractual rights and the efficiency is negatively related with the country risk. This leads to the following hypothesis:

Hypothesis 2: Countries that are characterized by more political and economic risk exhibit higher piracy rates and revenue losses for foreign copyrightbased companies than countries with low risk characteristics.

The second group of factors relates to the size of the user base of copyright related products (e.g. Givon, Mahajan and Muller, 1995; Slive and Bernhardt, 1998). The size of the user base becomes important when there is a positive consumption or network externality which exists if the utility for the product increases with piracy because it increases the number of other individuals using it (Takeyama, 1997; Shy and Thisse, 1999). The risk of piracy increases with the number of owners of complementary products - such as televisions, personal computers, CD-players - since they are potential users of copyright related products. For instance, Gallegos (1999) and Moorehouse (2001) indicated that Internet software piracy has increased considerably due to the explosive growth in the number of people that have access to the Internet and the advances in technology that have increased the ease and speed of 
access to the Internet. Unlike the physical distribution of pirated software, the Internet allows pirated products to be transferred from a host computer to a PC without anyone's knowledge. Similarly, Ostergard (2000) stressed that the great advances in technology have resulted in easier methods for duplicating that same technology and associated products. For instance, the introduction of video recorders in the consumer market has brought with it a capacity to duplicate videotapes, bringing about potentially massive violations of entertainment industry copyright protection. Likewise, Silva and Ramello (2000) indicated that the introduction of recording equipment by Philips and other producers in the late 1960s resulted in private music copying by individual consumers using their home equipment. We therefore hypothesize:

Hypothesis 3: Countries that are characterized by a high density of computers exhibit higher piracy rates and revenue losses for foreign copyright-based companies than countries that have a low computer density.

Hypothesis 4: In the motion picture video and entertainment industries, countries that are characterized by a high density of television sets exhibit higher piracy rates and revenue losses for foreign copyright-based companies than countries that have a low television density.

The third group of determinants is related to the importance of trade in a country and its effect on the protection of copyright-based materials and fair market access. Open countries with high export shares have many domestic firms that need safeguarding of their own unique assets to remain competitive in the international arena (Gould and Gruben, 1996). These countries are more careful in their international relations because they are more dependent on them for economic growth. Therefore, they will be more inclined to respect intellectual 
property rights of foreign firms due to the fear of repercussions (such as trade boycotts) in case they would violate international agreements (Stegemann, 2000; Stolpe, 2000). Thus, we expect that the piracy measures are negatively related with a country's level of export. Another interesting measure is the share of high technology exports in total exports. It is a good indicator of the technology level of that particular country. The higher the level of technology, the more likely it is that unauthorized production and distribution of copyrightbased materials will take place since the skills and related technologies are available (see e.g. Marulidharan and Phatak, 1999; Ostergard, 2000). Important examples are CDs from the Philippines (Gonzales da Newman, 2001) and computer software from Hong Kong (Economist, 1998). When countries lack a minimum technology base, they will not be able to copy high technology products. We would therefore expect a positive relationship between the piracy measures and the share of high technology exports. We suggest the following hypotheses:

Hypothesis 5: Countries that strongly depend on exports exhibit lower piracy rates and revenue losses for foreign copyright-based companies than countries that are less dependent on exports.

Hypothesis 6: Countries that have a relatively large share of high-technology products in exports exhibit higher piracy rates and revenue losses for foreign copyright-based companies than countries that have a relatively small share of high-technology products in exports.

The last essential group comprises of legal factors. Intellectual property rights protection has two components: a statute component and an enforcement component. We need to consider 
both the strength of the laws and the enforcement of those laws to comprise the extension of intellectual property rights protection in a country (Samuelson, 1999; Ostergard, 2000). The enforcement of intellectual property rights embodies two tasks: preventing their infringement by free-riders and disciplining attempts by the rights holders to extend them beyond the terms of the grant (Maskus, 1998). For the enforcement of these laws, countries must have institutional structures and financial resources (Ostergard 2000). In empirical studies, intellectual property rights protection is frequently measured by the country's membership of international conventions on the subject (Ginarte and Park, 1997). Burke (1996), for instance, tested the importance of convention membership on piracy levels in the audio software industry. Several international conventions (such as Berne 1887, Rome 1961, Geneva Phonogram 1971) have tried to enforce copyright protection for artists and producers in the music industry. Burke (1996) found that countries that are members of those convention agreements have lower piracy rates than countries that are not. We therefore formulate the following hypothesis:

Hypothesis 7: The existence of an extensive copyright protection system in a country reduces the piracy rates and the revenue losses suffered by foreign copyright-based companies.

\section{The data}

The data set is composed of data from various sources. The primary sources we employ are the International Intellectual Property Alliance (IIPA) and the World Bank. Both provide information regarding the characteristics of a country. The former provides data on the estimated copyright piracy rate levels and the associated estimated aggregate revenue losses 
suffered by U.S. copyright-based industries in the countries that are listed on the special 301 report 2001. The world development indicators database of the World Bank provides an extensive collection of data about social, financial, economic, and political indictors. For this study we use only those countries for which sufficient data are available from both sources. These countries are listed in table 3 .

Insert Table 3 about here

The dependent variables are piracy rate and estimated revenue loss suffered by the four US creative industries due to piracy in each country in the analyses (see appendix A). In all regressions for the estimated suffered revenue losses in US dollars we will use the log value of the dependent variable revenue loss. Since revenue losses are defined as $\geq 0$, the use of the $\log$ value of specific revenue losses is an attractive feature.

We include a country's domestic market size to test hypotheses $1 \mathrm{a}$ and $\mathrm{b}$. We proxy market size by the host country's gross domestic product (GDP) following, for instance, Buckley and Casson (1981) and Lee and Mansfield (1996). Domestic market size will also be logged in all equations since we expect percentage differences in market size, rather than absolute dollar differences in GDP, to be linearly related to piracy rates and log value of the revenue losses due to piracy respectively.

The level of exports is measured by the share of exports of goods and services in GDP. High technology exports are measured as the percentage of total manufactured exports made up by high technology products. The values of the number of PCs and the number of TVs per 1000 persons are conversed into natural logarithm values. This procedure renders the relationships between rates and revenue losses and each of the explanatory variables in percentage terms, 
either by definition of the variable itself as a percentage, or by transformation of the relationship to log values (Orr, 1974).

The risk of a country is measured by the country risk rating published by Euromoney. Euromoney rates countries on a scale from 1 (very high risk) to 100 (no risk) ${ }^{\mathrm{iv}}$.

A variety of data sources on international legal protection for copyright-based materials were consulted to determine if protection is available in a particular country for either a U.S. or a foreign company. An index is constructed which indicates how strongly a country will provide intellectual property rights protection. The variable equals one if the country in question meets all the following three criteria: (a) protection is available under the national copyright law of a particular country; (b) patent protection is available in national law; (c) the country belongs to the maximum number (5) of intellectual property rights treaties. The involved five convention memberships are Berne Convention, Universal Copyright Convention, Paris Convention, European Patent Convention and Patent Cooperation Treaty ${ }^{\mathrm{V}}$. Table 3 shows an overview of a country's membership of the intellectual property rights treaties and if it has a national law for both copyright and patent protection as of 1998. To calculate the copyright protection system index, we recoded a membership into the value 1 and also the existence of protection in the national laws (yes $=1)$ otherwise the value equals 0 $($ no $=0)$. The protection value for a country is the number of conditions satisfied (number of 1 's received) divided by the maximum number of conditions to be satisfied. The law index varies from one (strong protection) to zero (low protection).

-Insert Table 4 about here-

Table 4 presents the descriptive statistics of the variables for the 44 countries in the sample. The mean value of the variable market size is 146.62 billion US dollars but the standard 
deviation is high (249.15), with market size values ranging from 5.20 (for Estonia) to 1190.00 billion US dollar (for Italy). The mean country risk rating is 0.52 but the standard deviation is high with values ranging from 0.23 (for Russian Federation) and 0.87 (for Italy). The reported number of PCs per 1000 persons is, on average, 53.72. This mean is low because a number of countries clearly demonstrate a low density of PCs. The minimum value belongs to India with less than 3 PCs per 1000 persons, while Israel shows the highest value of 217.39 PCs per 1000 persons. All countries show a significantly higher density of televisions. The minimum figure for the density ratio is $47 \mathrm{TVs}$ per 1000 persons (for Vietnam) compared to less than 3 computers per 1000 persons for India. Mean exports of goods and services (as a percentage of GDP) in 1999 is 34.53 percent. The country with the lowest export ratio in the sample is Paraguay (2.22\%), while Malaysia is the country with the highest export ratio $(115.24 \%)$. Malaysia even exports more than its gross domestic product, signaling an open economy that is very dependent on trade. However, looking at the share of high-technology exports in the total manufactured exports, Paraguay is not ranked as lowest but Pakistan is, with a hightechnology share of only 0.12 . The Philippines replace Malaysia as the top-seeded country considering high technology exports. On average, the share of high-technology exports of the countries in the sample is 11.39 percent. The copyright protection system index varies from no legislative protection (Kuwait) to strong protection (for instance, Greece, Italy, and Israel). The sample includes a substantial number of countries from different regions: East Europe (10), Asia (11), Middle East (8) and Latin America (13). It is clear that countries from Western Europe (2) and Africa (0) do not have the highest monitoring priority by the U.S. government. In Western Europe, overall the countries adequately and effectively protect US intellectual property rights and provide fair and equitable market access to US companies which produce copyright-based materials (see Yang, 1998; Markusen, 2001). In Africa, only few business activities occur, reducing the overall risk of piracy. 


\section{Results}

Table 5 shows the results of the model OLS estimations for piracy rates. We test our model for four US copyright-based industries where intellectual property rights protection matters: business software applications, sound recording and musical compositions, motion pictures, and entertainment software.

-Insert Table 5 about here

Our first hypothesis 1a implies a negative relationship between market size and piracy rate. The results, however, show no clear relationship between market size and piracy rates. The second hypothesis based on the economic development and stability group literature argues that the level of piracy rates for the copyright-based products is positively associated with countries with high risk characteristics, such as political and economic instability. We do find that for all four industries low country risk results in significantly lower piracy rate, although entertainment software shows a weak relationship. Thus, the results support hypothesis two for the business software applications, recording and musical compositions, and motion pictures industries. Regarding the presence of related products we find that the presence of a high density of television sets in a country positively and significantly influences the motion pictures piracy rate. Hypothesis four is therefore supported for this particular creative industry. On the other hand, we do not find a clear effect of the penetration of PCs on the piracy rates in any of the four creative industries. We therefore find no support for hypothesis three in case of piracy rates.

We also hypothesize that the countries depending on exports are more inclined to respect intellectual property of foreign firms. However, the results do not support the relationship between dependence on exports and copyright protection. We therefore cannot confirm 
hypothesis five. In hypothesis six we argue that the higher the level of technology, the more likely that unauthorized production and distribution of copyright-based materials would take place since the skills and related technologies are available. However, no conclusive evidence is found for the relationship between a country's technology level and the piracy rate for the studied four creative industries.

Hypothesis seven argues that countries with strong copyright protection systems have low piracy rates. The estimates of the indicator for the country's copyright protection system is negative and for two industries significantly different from zero. Thus, a sufficient legal system with strong copyright protection generally results in lower piracy rates. This effect is particularly strong and significant in case of the entertainment software industry and business software applications industry. Hence, these results confirm hypothesis seven.

Interestingly, we find strong differences in piracy rates between regions in the world. Our benchmark region is Latin America. The estimates show that Western European and Asian countries demonstrate a higher illegal use of business software applications than their Latin American counterparts. Furthermore, the Eastern European countries show a larger inclination to copy entertainment software materials than countries in other regions.

Insert Table 6 about here

Table 6 presents the results of the model OLS estimations for revenue losses suffered by the four US copyright-based industries abroad. When considering the estimated dollar revenue losses for US firms due to piracy in other countries we find related, though slightly different, results as for piracy rates. First of all, contrary to the results for piracy rates, we now find strong evidence of a positive influence of the market size of the host country and the estimated revenue losses of US creative companies resulting from illegal copying of business 
software applications, entertainment software, sound recording and musical compositions and music pictures industries. The estimates of market size therefore strongly support hypothesis $1 b$.

The results on country risk are conflicting. In case of the motion pictures industry, it confirms our expectation that higher stability results in a decline of revenue losses for US companies. However, we find that in case of business software applications, it actually results in an increase in revenue losses. Therefore, hypothesis two cannot be generally accepted for these four copyright-based industries studied.

Regarding the density of television sets we again find evidence that supports hypothesis four in case of the motion pictures industry. In this particular industry a high penetration of television sets therefore results in an increase in estimated revenue losses. Again we find that the density of PCs in a country has no influence on the estimated revenue losses in any of these four copyright-based industries. Thus, hypothesis three about the effect of the penetration of PCs on the estimated suffered revenue losses due to piracy is not supported.

Furthermore, the estimate of the indicator for country's export dependence is only positive and significant in case of the business software applications industry. This result is surprising because hypothesis five argues that a country with a high export ratio has an incentive to protect intellectual property right-based products of foreign companies. For the motion pictures industry we find that countries with high technology exports significantly and positively influence the estimated revenue losses suffered by US companies. It is relatively easy to copy motion pictures and videos once a country has a certain level of technological development. Thus, hypothesis six is partly supported.

We also hypothesize that a strong system to protect copyrights in a host country has a positive impact on the revenue losses of foreign copyright-based companies due to illegal copying of their products (hypothesis seven). The estimates of the indicator of a country's copyright 
protection system are not significantly different for zero. Thus, hypothesis seven is not supported for the estimated revenue losses of US companies due to piracy.

Again, we find considerable differences in the effect of specific regions. For US firms in copyright-based industries, the likelihood of a revenue loss due to business software applications piracy is significantly smaller in Western Europe, Asia, and the Middle East than in Latin American countries. In the entertainment software industry we find evidence that countries in Eastern Europe show the highest likelihood of revenue losses for US companies due to piracy of entertainment materials. Furthermore, the regions Asia and Middle East behave differently from the other regions, in particular in comparison with Latin America, in the sound recording and musical compositions industry and motion pictures industry respectively. The estimate of Asia is negative, while the estimate of the Middle East is positive and significant different from zero.

\section{Discussion}

To determine the cross national variation in piracy rates and the resulting estimated revenue losses for US copyright-based industries (business software applications, recording and musical compositions, motion pictures, and entertainment software), we have considered four groups of variables as identified by previous studies (e.g. Burke, 1996; Husted, 2000; Marron and Steel, 2000): economic development and stability, penetration of related products, trade relations, and legal factors. This section discusses the most important findings of our study. In doing so, it is important to emphasize that only a sample of countries is listed on the special 301 report. These countries have the highest monitoring priority by the US government. This decision is based on the weakness of their intellectual property rights protection system, particularly for copyrights. Furthermore, the piracy data are only based on four US copyright- 
based industries. This implies that some caution has to be taken into account for the generalization of the findings.

Regarding the economic variables, the results of our analyses strongly support the hypothesis that in larger markets, the estimated revenue losses suffered by US copyright-based companies due to unauthorized (re)production and distribution of their copyright-related materials in large host markets are considerable, even when these countries are characterised by relatively low piracy rates. Therefore, even though host countries may have relatively low piracy rates, the overall estimated revenue losses suffered by foreign copyright-based companies due to piracy in these economies are not necessarily negligible. This result is in line with Tang and Tunzelmann (2000) who emphasize that large markets offer many opportunities for piracy, given that the identification of the unauthorized producers and users of the illegal products is more difficult in larger than in smaller markets. Even piracy at a small scale can then create a considerable loss for the creative firm.

We find no significant relationship between market size and piracy rates. Even though most studies indicate that larger countries will have better intellectual property rights protection out of fear for retaliation (Samuelson, 1999; Stegemann, 2000) or to remain an attractive location for FDI (Buckley and Casson, 1981; Dunning, 1993; Lee and Mansfield, 1996; Seyoum, 1996), this expectation is not confirmed in our study. This can be explained by the fact that other factors related to market size capture the economic situation of the country better than market size measured by GDP. For instance, Ginarte and Park (1997), Husted (2000) and Marron and Steel (2000) emphasized that it is not only one variable indicating the level of economic development per se that influences the provision of intellectual property rights, but rather an group of determinants of economic development, such as income, stability and political climate, demand for luxury goods, technology level, market size, and market access and openness. 
To capture these elements, this study therefore also considered country risk as a potential explanation for piracy rates and losses. It is measured as a combination of economic performance, political stability, access to domestic markets, and a country's debt situation. In general, the evidence shows that countries that have a high-risk profile offer little protection of copyrights, resulting in high piracy rates, particularly in the business software application, recording and musical compositions, and motion pictures industries. This result confirms Ginarte and Park (1997). Countries that are very risky are therefore uninteresting locations for business activities of US firms in the copyright-based industries. For piracy rates, the risk variable therefore captures the elements mentioned by Marron and Steel (2000).

The results regarding the actual estimated revenue losses are conflicting. Contrary to our expectation, we find that for the business software applications industries low risk countries are actually associated with large revenue losses suffered by foreign creative companies due to piracy in this industry. This surprising phenomenon can be attributed to the fact that relatively developed and stable economies have enough resources to invest in (copying) business software materials. In general, state of the art business software applications products are developed and used in countries with high technology knowledge industries. These countries are characterized by low risk. Thus, it is likely that revenue losses suffered by copyright-based companies due to piracy of their products are the highest in these (stable) countries.

The second group of variables we considered in our conceptual model is the penetration of related products. Our results confirm the expectation that the risk of piracy increases with the number of owners of complementary products, which is in line with previous studies by Takeyama (1997) and Shy and Thisse (1999). This is particularly true in case of the motion pictures industry for the spread of televisions. The fact that many households possess TVs and recording equipments encourages the illegal copying of videos. 
However, at the same time we find that the penetration of computers has no significant effect on the piracy rates and losses occurring in any of the four studied industries. We attribute this result to the fact that computers are still a relatively new phenomenon. They are not nearly as wide-spread as televisions are and not every household currently has access to a computer, the Internet, or the necessary software to engage in illegal activities, in particular for the countries listed on the 301 report.

The third group of factors considered in this study is trade-related measures. The results for the two variables introduced here are disappointing. We find no proof for the hypothesis that exporting countries exhibit lower piracy rates and losses. This result is not in line with Stegemann (2000) and Stolpe (2000). In addition, only for the motion picture industry we find that high technology exports do encourage financial losses due to illegal copying. This result confirms for all the sample countries the earlier finding of Gonzales da Newman (2001) for CD piracy in the Philippines.

It is important to stress that the majority of countries in our sample are middle-income countries. Particularly many middle-income countries, even when they are export-oriented, still have problems accepting the legitimacy of the monopoly claims over intellectual property as asserted by companies. Maskus (1998) emphasized that middle-income countries indeed may weaken their protection systems because they have the ability to imitate new technology that can help to stimulate their economy. Many countries in our sample will therefore, even though they export a lot and could fear for retaliation, prefer to allow piracy. Only when economies move from the middle-income to the high-income group, intellectual property rights protection usually increases sharply.

In addition, intellectual property rights protection is a tremendously fluid concept strongly affected by cultural values. It is very much rooted in the Western cultural values of liberalism and individual rights, which are less important in many of our sample countries. Indeed, the 
largest differences in intellectual property rights protection occur along the North-South lines (e.g. Yang, 1998; Husted, 2000). Table 3 confirms that for instance the Arab countries (Saudi Arabia, Oman, Kuwait) have very little intellectual property protection. Countries that do not value liberalism and individual rights very highly, will have less scruples about piracy.

The theoretical debate of the effect of the technology level of a country on piracy is still undecided. Our present results are in line with Marron and Steel (2000), who found no convincing evidence for the effect of technology on piracy. However, despite these results, many innovative firms do perceive substantial revenue losses in foreign markets from illegal copying (Maskus, 1998). The opportunities for international free riding have increased because technologies for copying software, entertainment products, books, transmissions, and certain technologies have become cheaper and more reliable. This development has therefore increased the pressure for strong international standards on intellectual property rights protection (Maskus, 1998). As a consequence, each member of the World Trade Organization has agreed to develop an intellectual property rights system according to minimum standard. However, for the period under investigation here, the countries still had time to meet the obligations. The results therefore may not be visible yet.

Finally, we considered legal factors. Technological advantage is among the US creative companies' most important strengths, as it is for most multinational enterprises. Slack intellectual property rights protection in host countries can lead to a rapid erosion of this key advantage. Locating R\&D in a host country with lower intellectual property protection levels increases the multinational enterprise's exposure to the possibility of losing technological secrets and advantages to local competitors (see e.g. Muralidharan and Phatak, 1999). An extensive copyright protection system can help to protect the intellectual property of these companies. Our evidence shows that the existence of a strong protection system in a host 
country indeed reduces the piracy rates of various foreign copyright-related materials (in particular business software applications and entertainment software).

In this study we treated the four different copyright-based industries almost as undifferentiated. However, it is likely that differences exist between the industries that were not considered here. Further research should pay attention to the specificity of each context and should try to extent the number of countries in the sample. Another interesting research focus would be to investigate whether the universal consideration regarding the findings for patent-related products and industries are also valid for copyright-related products and industries. Given this research agenda, our contribution has certain limitations but it also provides us with some interesting answers to a number of relevant questions regarding the determinants of piracy taking country characteristics into account.

We implicitly modelled that individual countries select their copyright protection policy as a result of economic and legal conditions. Observed piracy rates and the estimated revenue losses suffered by copyright-based companies due to piracy are the outcome of these policies, their implementation, and the response of individuals and companies to them. An alternative approach, not adopted here, would be to analyse how individuals decide whether to pirate copyright-related products based on the costs and benefits facing them.

\section{Conclusion}

The piracy rates of copyright-related products and the revenue losses suffered by US copyright-related companies due to illegal production and distribution of their products abroad show considerable differences between countries/regions but also between the different kinds of copyright-based industries. The purpose of this study was to examine these cross-national variations in piracy of U.S. copyright-related products in four creative industries: business software applications, recording \& musical compositions, motion pictures, and entertainment 
software. We considered four groups of country-specific variables, economic development and stability, legal issues, trade relations, and penetration of related products, to explain the cross-national piracy differences for these creative industries. It is shown that the disaggregation of the profile of a country is helpful in analyzing the piracy issue around the world.

Our most remarkable finding concerns the differences among the determinants of piracy rates and the resulting revenue losses suffered by US copyright based industries due to piracy. We find that a large market size of a host country results in higher revenue losses for the creative industries, even if the piracy rates in these industries are relatively low. Furthermore, we find that, in general, low risk countries show lower piracy rates and that the revenue losses suffered by US companies producing and selling copyright-related products in these countries are positively related with the risk, with one exception: revenue losses due to business software applications piracy. The evidence shows significant differences in piracy between separate regions in the world. Taken together, these results suggest that individual countries select their copyright protection policy as a function of economic, legal and social conditions, as well as differences in cultural traditions. The observed countries' piracy rates for the US copyright-based industries and the revenue losses suffered by US companies due to piracy in these industries are the outcome of these policies and their implementation. 


\section{References}

Buckley, P.J. and M.C. Casson (1981) "The optimal timing of a foreign direct investment". Economic Journal 91: 75-87.

Burke, A.E. (1996) "How effective are international copyright conventions in the music industry?". Journal of Cultural Economics 20: 51-66.

Burke, A.E. (2000) "Legal structure and strategic regulation of intellectual property: who pays for R\&D in arts markets?”. Recherches Economiques de Louvain 66: 193-211.

Conner, K.R. (1995) “Obtaining strategic advantage from being imitated: when can encouraging ‘clones’pay?”. Management Science 41: 209-225.

Conner, K.R. and R.P. Rumelt (1991) "Software piracy: an analysis of protection strategies". Management Science 37: 125-139.

Deardorff, A.V. (1992) "Welfare effects of global patent protection". Economica 59: 35-51.

Deardorff, A.V. (1995) “The appropriate extent of intellectual property rights in art”. Journal of Cultural Economics 19: 119-130.

Dunning, J. (1993) Multinational Enterprises and the Global Economy. Addison-Wesley, London.

Economist, the (1998) "Software piracy: better than the real thing". January 24, 71-72. 
Fenwick and West LLP (2000) Chart of International Legal Protection for Software. Fenwick and West report, Palo Alto.

Gallegos, F. (1999) "Software Piracy: some facts, figures, and issues”. Information Systems Security 8 (4): 34-56.

Ginarte, J.C. and W.G. Park (1997) "Determinants of patent rights: a cross-national study". Research Policy 26: 283-301.

Givon, M., V. Mahajan and E. Muller (1995) "Software piracy: estimation of lost sales and the impact on software distribution". Journal of Marketing 59: 29-37.

Gould, D.M. and W.C. Gruben (1996) "The role of intellectual property rights in economic growth". Journal of Development Economics 48: 323-350.

Gonzales da Newman, D. (2001) "Piracy fight united labels in Philippines". Billboard, 113 (14): 70 .

Husted, B.H. (2000) “The impact of national culture on software piracy". Journal of Business Ethics 26: 197-211.

IIPA (1998) 1998 Special 301 Report. IIPA annual report, February.

IIPA (1999) 1999 Special 301 Report. IIPA annual report, February. 
IIPA (2000) 2000 Special 301 Report. IIPA annual report, February.

IIPA (2001), 2001 Special 301 Report. IIPA annual report, February.

Katz, M. and C. Shapiro (1985) "Network externalities, competition, and compatibility". American Economic Review 75: 424-440.

Katz, M. and C. Shapiro (1986) "Technology adoption in the presence of network externalities". Journal of Political Economy 94: 822-841.

Knack, S. and P. Keefer (1995) "Institutions and economic performance: cross-country test using alternative institutional measures”. Economics and Politics 7: 207-227.

Lee, J. and Mansfield, E. (1996) "Intellectual property protection and U.S. foreign direct investment". Review of Economics and Statistics 77 (2): 181-186.

Legrand, E. (1998) "EC starts inquiry into effects of EU piracy". Billboard 110 (46): 6.

Liebowitz, S.J. (1985) “Copying and indirect appropriability: photocopying of journals". Journal of Political Economy 93: 945-957.

Mansfield, E. (1994) "Intellectual property protection, foreign direct investment, and technology transfer, international finance corporation". discussion paper no. 19. World Bank, Washington, DC. 
Maskus, K.E. (1998) "The international regulation of intellectual property". Weltwirtschaftliches Archiv 134 (2): 186-208.

Markusen, J.R. (2001) “Contracts, intellectual property rights, and multinational investment in developing countries". Journal of International Economics 53: 189-204.

Marron, D.B. and Steel, D.G. (2000) "Which countries protect intellectual property? the case of software piracy". Economic Inquiry 38 (2): 159-174.

Mille, A. (1997) "Copyright in the cyberspace era". European Intellectual Property Review 19: $570-577$.

Moorehouse, J.C. (2001) "Property rights, technology, and internet distribution". Journal of Technology Transfer 26: 351-361.

Muralidharan, R. and Phatak, A. (1999) "International R\&D activity of US MNCs: an empirical study with implications for host government policy". Multinational Business Review 7(2): 97-105.

Oetzel, J.M., R.A. Bettis and M. Zenner (2001) “Country risk measures: how risky are they?”. Journal of World Business 36: 128-145.

Orr, D. (1974) "The determinants of entry: a study of the Canadian manufacturing industries". Review of Economics and Statistics 56 (February): 58-66. 
Ostergard, R.L. jr. (2000) “The measurement of intellectual property rights protection". Journal of International Business Studies 31 (2): 349-360.

Rapp, R.T. and Rozek, R.P. (1990) "Benefits and costs of intellectual property protection in developing countries". Journal of World Trade 24: 75-102.

Samuelson, P. (1996) "Regulation of technologies to protect copyrighted works". Communications of the ACM 39(7): 17-22.

Samuelson, P. (1999) "Implications of the agreement on trade related aspects of intellectual property rights for cultural dimensions of national copyright laws". Journal of Cultural Economics 23: 95-107.

Seyoum, B. (1996) “The impact of intellectual property rights on foreign direct investment". Columbia Journal of World Business 31: 50-59.

Shy, O. and J. Thisse (1999) “A strategic approach to software protection". Journal of Economics and Management Strategy 8: 163-190.

Silva, F. and Ramello, G.B. (2000) "Sound recording market: the ambiguous case of copyright and piracy". Industrial and Corporate Change 9 (3): 415-442.

Simon, E. (1996) "Innovation and intellectual property protection: the software industry perspective". Columbia Journal of World Business 31: 30-37. 
Singer, A.E., J. Calton and M. Singer (2001) "Profit without copyright". Small Business Economics 16: 149-156.

Siwek, S. (2000) "Copyright industries in the U.S. economy: the 2000 report". IIPA economic report, December.

Slive, J. and D. Bernhardt (1998) "Pirated for profit". Canadian Journal of Economics 31: 886-899.

Stegemann, K. (2000) “The integration of intellectual property rights into the WTO system". World Economy 23: 1237-1267.

Stolpe, M. (2000) "Protection against software piracy: a study of technology adoption for the enforcement of intellectual property rights". Economics of Innovation and New Technology 9: $25-52$.

Takeyama, L.N. (1994) “The welfare implications of unauthorized reproduction of intellectual property in the presence of demand network externalities". Journal of Industrial Economics 17: $155-166$.

Takeyama, L.N. (1997) “The intertemporal consequences of unauthorized reproduction of intellectual property". Journal of Law and Economics 40: 511-522.

Tang, P. and N. von Tunzelmann (2000) "Management, governance and intellectual property: electronic publishing in the UK”. Journal of Management and Governance 4: 299-318. 
Tysver, D.A. (2000) Bitlaw: a resource on technology law. Beck \& Tysver, P.L.L.C., Minneapolis.

WIPO (2001) Intellectual handbook: policy, law and use. WIPO publication.

Yang, Y. (1998) "Why do southern countries have little incentive to protect northern intellectual property rights?”. Canadian Journal of Economics 31: 800-816. 


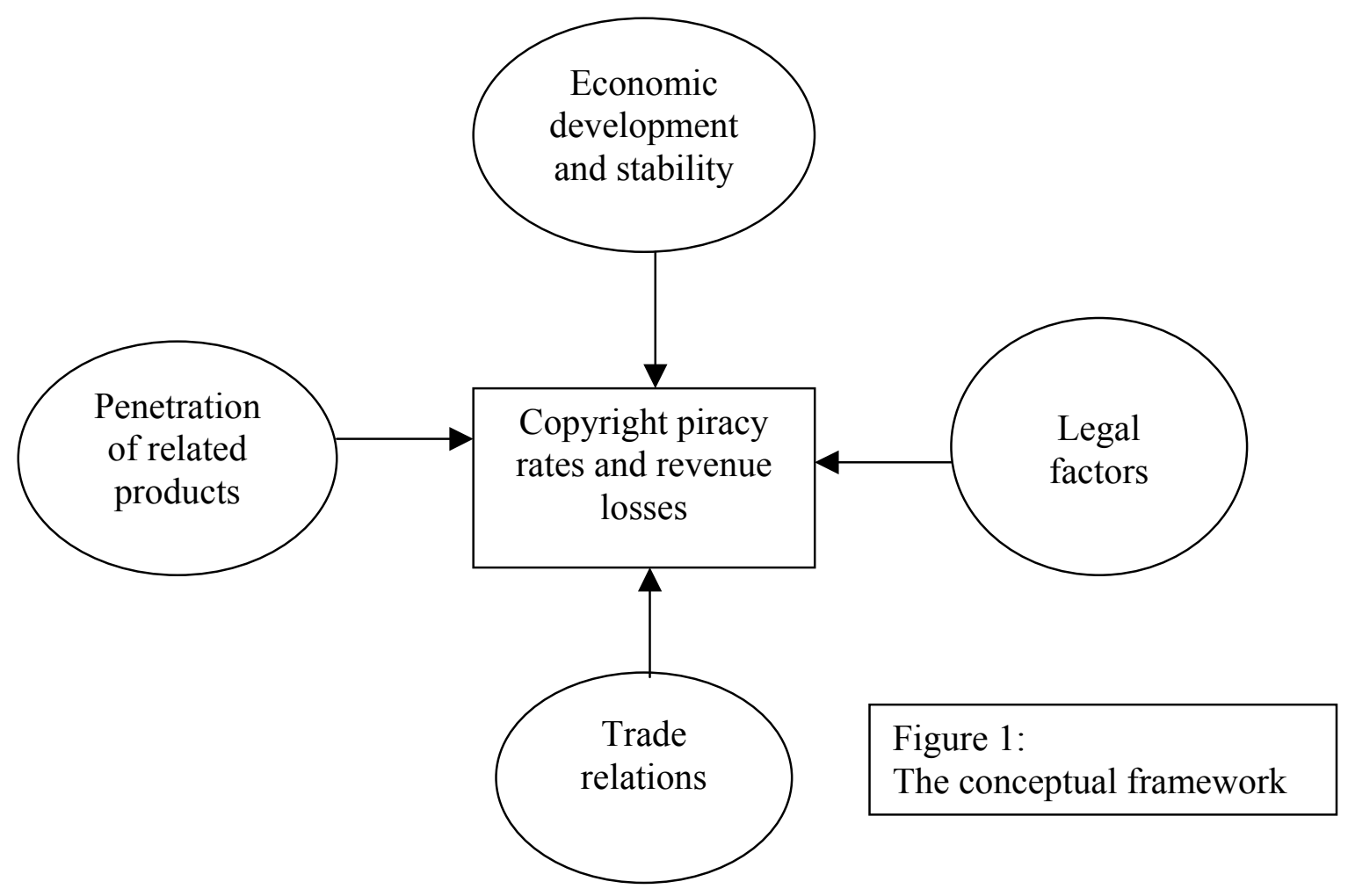




\begin{tabular}{|l|c|r|r|r|r|}
\hline \multicolumn{7}{|c|}{$\begin{array}{l}\text { Table 1 } \\
\text { Descriptive statistics of countries copyright piracy rates of US copyright-based } \\
\text { products in 1999 (in percentage) }\end{array}$} \\
\hline & $\begin{array}{c}\text { Sample of } \\
\text { Countries }\end{array}$ & $\begin{array}{c}\text { Mean } \\
\text { piracy rate }\end{array}$ & $\begin{array}{c}\text { Standard } \\
\text { Deviation }\end{array}$ & Minimum & Maximum \\
\hline $\begin{array}{l}\text { Business Software } \\
\text { Applications }\end{array}$ & 39 & 69.69 & 15.00 & 42.00 & 98.00 \\
\hline $\begin{array}{l}\text { Recording \& Musical } \\
\text { Compositions }\end{array}$ & 43 & 50.65 & 25.40 & 8.00 & 95.00 \\
\hline Motion Pictures & 44 & 61.34 & 26.21 & 15.00 & 100.00 \\
\hline Entertainment Software & 37 & 78.46 & 15.60 & 50.00 & 99.00 \\
\hline
\end{tabular}

Table 2

Descriptive statistics of foreign copyright piracy revenue losses suffered by US copyright-based industries in 1999 (in millions of US dollars)

\begin{tabular}{|l|c|r|r|r|r|}
\hline & $\begin{array}{c}\text { Sample of } \\
\text { Countries }\end{array}$ & \multicolumn{1}{c|}{$\begin{array}{c}\text { Mean } \\
\text { Loss }\end{array}$} & $\begin{array}{l}\text { Standard } \\
\text { Deviation }\end{array}$ & Minimum & Maximum \\
\hline $\begin{array}{l}\text { Business Software } \\
\text { Applications }\end{array}$ & 39 & 69.06 & 98.04 & 1.60 & 437.20 \\
\hline $\begin{array}{l}\text { Recording \& Musical } \\
\text { Compositions }\end{array}$ & 43 & 37.40 & 66.60 & 0.10 & 300.00 \\
\hline Motion Pictures & 44 & 28.64 & 48.34 & 0.50 & 250.00 \\
\hline Entertainment Software & 37 & 80.63 & 226.82 & 0.10 & 1382.50 \\
\hline
\end{tabular}




\begin{tabular}{|c|c|c|c|c|c|c|c|}
\hline \multicolumn{8}{|c|}{$\begin{array}{c}\text { Table } 3 \\
\begin{array}{c}\text { Overview of countries monitored by IIPA, their membership of intellectual property right treaties, and the protection } \\
\text { of intellectual property rights under national laws }\end{array} \\
\end{array}$} \\
\hline \multirow[t]{2}{*}{ Country } & \multicolumn{5}{|c|}{ Intellectual Property Right Treaties } & \multicolumn{2}{|c|}{\begin{tabular}{|c|} 
Existence of National \\
Protection Law \\
\end{tabular}} \\
\hline & $\begin{array}{c}\text { Berne } \\
\text { Convention }\end{array}$ & \begin{tabular}{c|c|} 
Universal \\
Copyright \\
Convention \\
\end{tabular} & $\begin{array}{c}\text { Paris } \\
\text { Convention }\end{array}$ & \begin{tabular}{c|c} 
European \\
Patent \\
Convention
\end{tabular} & \begin{tabular}{c|} 
Patent \\
$\begin{array}{c}\text { Cooperation } \\
\text { Treaty }\end{array}$
\end{tabular} & \begin{tabular}{c|c} 
Copyright \\
Protection \\
Law
\end{tabular} & $\begin{array}{l}\text { Patent } \\
\text { Protection } \\
\text { Law }\end{array}$ \\
\hline Argentina & $\overline{\text { Yes }}$ & Yes & Yes & $\mathrm{No}$ & No & No & No \\
\hline Bolivia & Yes & Yes & Yes & $\mathrm{No}$ & No & No & No \\
\hline Brazil & Yes & Yes & Yes & No & Yes & Yes & No \\
\hline Chile & Yes & Yes & Yes & No & No & No & No \\
\hline China & Yes & Yes & Yes & No & Yes & Yes & No \\
\hline Colombia & Yes & Yes & Yes & No & No & Yes & No \\
\hline \begin{tabular}{|l|} 
Costa Rica \\
\end{tabular} & Yes & Yes & Yes & $\mathrm{No}$ & Yes & Yes & No \\
\hline Czech Republic & Yes & Yes & Yes & No & Yes & Yes & No \\
\hline Dominican Republic & Yes & Yes & Yes & No & Yes & Yes & Yes \\
\hline Egypt & Yes & $\overline{\text { No }}$ & Yes & No & No & Yes & $\overline{\text { No }}$ \\
\hline El Salvador & Yes & Yes & Yes & $\mathrm{No}$ & $\mathrm{No}$ & Yes & No \\
\hline Estonia & Yes & No & Yes & $\mathrm{No}$ & Yes & Yes & No \\
\hline Greece & Yes & Yes & Yes & Yes & Yes & Yes & Yes \\
\hline Guatemala & Yes & Yes & Yes & No & No & No & No \\
\hline Hungary & Yes & Yes & Yes & $\mathrm{No}$ & Yes & Yes & No \\
\hline India & Yes & $\overline{\text { Yes }}$ & Yes & $\mathrm{No}$ & Yes & Yes & No \\
\hline Indonesia & Yes & No & Yes & $\mathrm{No}$ & Yes & Yes & No \\
\hline Israel & Yes & $\overline{\text { Yes }}$ & Yes & $\mathrm{No}$ & Yes & Yes & $\overline{\text { Yes }}$ \\
\hline Italy & Yes & Yes & Yes & Yes & Yes & Yes & Yes \\
\hline Jordan & Yes & $\overline{\text { No }}$ & Yes & No & No & Yes & No \\
\hline Korea Republic & Yes & Yes & Yes & $\mathrm{No}$ & Yes & Yes & Yes \\
\hline Kuwait & No & $\overline{\mathrm{No}}$ & No & $\mathrm{No}$ & No & No & No \\
\hline Latvia & Yes & No & Yes & $\mathrm{No}$ & Yes & Yes & No \\
\hline Lebanon & Yes & $\overline{\text { Yes }}$ & Yes & $\mathrm{No}$ & No & Yes & No \\
\hline Lithuania (OCR) & Yes & No & Yes & $\mathrm{No}$ & Yes & Yes & No \\
\hline Malaysia & Yes & No & Yes & No & No & Yes & No \\
\hline Oman & Yes & No & Yes & No & No & Yes & No \\
\hline Pakistan & Yes & $\overline{\text { Yes }}$ & $\mathrm{No}$ & $\mathrm{No}$ & No & Yes & No \\
\hline Paraguay & Yes & No & Yes & $\mathrm{No}$ & No & Yes & No \\
\hline Peru & Yes & Yes & Yes & $\mathrm{No}$ & No & Yes & No \\
\hline Philippines & Yes & No & Yes & No & No & Yes & No \\
\hline Poland & Yes & Yes & Yes & $\mathrm{No}$ & Yes & Yes & No \\
\hline Qatar & Yes & No & Yes & No & No & Yes & No \\
\hline Romania & $\overline{Y e s}$ & No & Yes & $\mathrm{No}$ & Yes & Yes & No \\
\hline Russian Federation & Yes & Yes & Yes & $\mathrm{No}$ & Yes & Yes & No \\
\hline Saudi Arabia & No & Yes & No & $\mathrm{No}$ & No & Yes & No \\
\hline Slovakia & Yes & Yes & Yes & $\mathrm{No}$ & Yes & Yes & No \\
\hline Taiwan & No & No & No & No & Yes & Yes & Yes \\
\hline Thailand & Yes & No & No & No & No & Yes & No \\
\hline Turkey & Yes & No & Yes & No & Yes & Yes & No \\
\hline Ukraine & Yes & Yes & Yes & No & Yes & Yes & No \\
\hline Uruguay & Yes & Yes & Yes & No & No & Yes & No \\
\hline Venezuela Republic & $\overline{\text { Yes }}$ & $\overline{\text { Yes }}$ & Yes & No & No & Yes & No \\
\hline Vietnam & No & No & Yes & $\mathrm{No}$ & Yes & Yes & No \\
\hline
\end{tabular}

Source: Fenwick and West (2000), IIPA (2001) and WIPO (2001). 
Table 4

Descriptive statistics of explanatory variables

\begin{tabular}{|c|c|c|c|c|c|c|}
\hline & & $\begin{array}{c}\text { Number of } \\
\text { Observations }\end{array}$ & Mean & $\begin{array}{c}\text { Standard } \\
\text { Deviation }\end{array}$ & Minimum & Maximum \\
\hline $\begin{array}{l}\text { Domestic } \\
\text { market in } \\
\text { Millions US } \\
\text { dollars }\end{array}$ & & 44 & 146.62 & 249.15 & 5.20 & 1190.00 \\
\hline $\begin{array}{l}\text { Country risk } \\
\text { rating }\end{array}$ & & 44 & 0.52 & 0.13 & 0.23 & 0.87 \\
\hline $\begin{array}{l}\text { Number of PC / } \\
1000 \text { persons }\end{array}$ & & 43 & 53.72 & 52.07 & 2.75 & 217.39 \\
\hline $\begin{array}{l}\text { Number of TV / } \\
1000 \text { persons }\end{array}$ & & 42 & 285.76 & 167.11 & 47.00 & 675.00 \\
\hline $\begin{array}{l}\text { Export of goods } \\
\& \text { Services }(\% \\
\text { of GDP) }\end{array}$ & & 42 & 34.53 & 21.88 & 2.22 & 115.24 \\
\hline $\begin{array}{l}\text { High- } \\
\text { technology } \\
\text { exports (\% of } \\
\text { manufactured } \\
\text { exports) }\end{array}$ & & 42 & 11.39 & 14.84 & 0.12 & 71.98 \\
\hline $\begin{array}{l}\text { Country } \\
\text { copyright } \\
\text { protection } \\
\text { system } \\
\end{array}$ & & 44 & 0.57 & 0.19 & 0.00 & 1.00 \\
\hline \multicolumn{7}{|l|}{ Region } \\
\hline & $\begin{array}{l}\text { Western } \\
\text { Europe }\end{array}$ & 44 & 0.045 & 0.21 & 0.00 & 1.00 \\
\hline & $\begin{array}{l}\text { Eastern } \\
\text { Europe }\end{array}$ & 44 & 0.23 & 0.42 & 0.00 & 1.00 \\
\hline & Asia & 44 & 0.25 & 0.44 & 0.00 & 1.00 \\
\hline & $\begin{array}{l}\text { Middle } \\
\text { East }\end{array}$ & 44 & 0.18 & 0.39 & 0.00 & 1.00 \\
\hline & $\begin{array}{l}\text { Latin } \\
\text { America }\end{array}$ & 44 & 0.30 & 0.46 & 0.00 & 1.00 \\
\hline
\end{tabular}




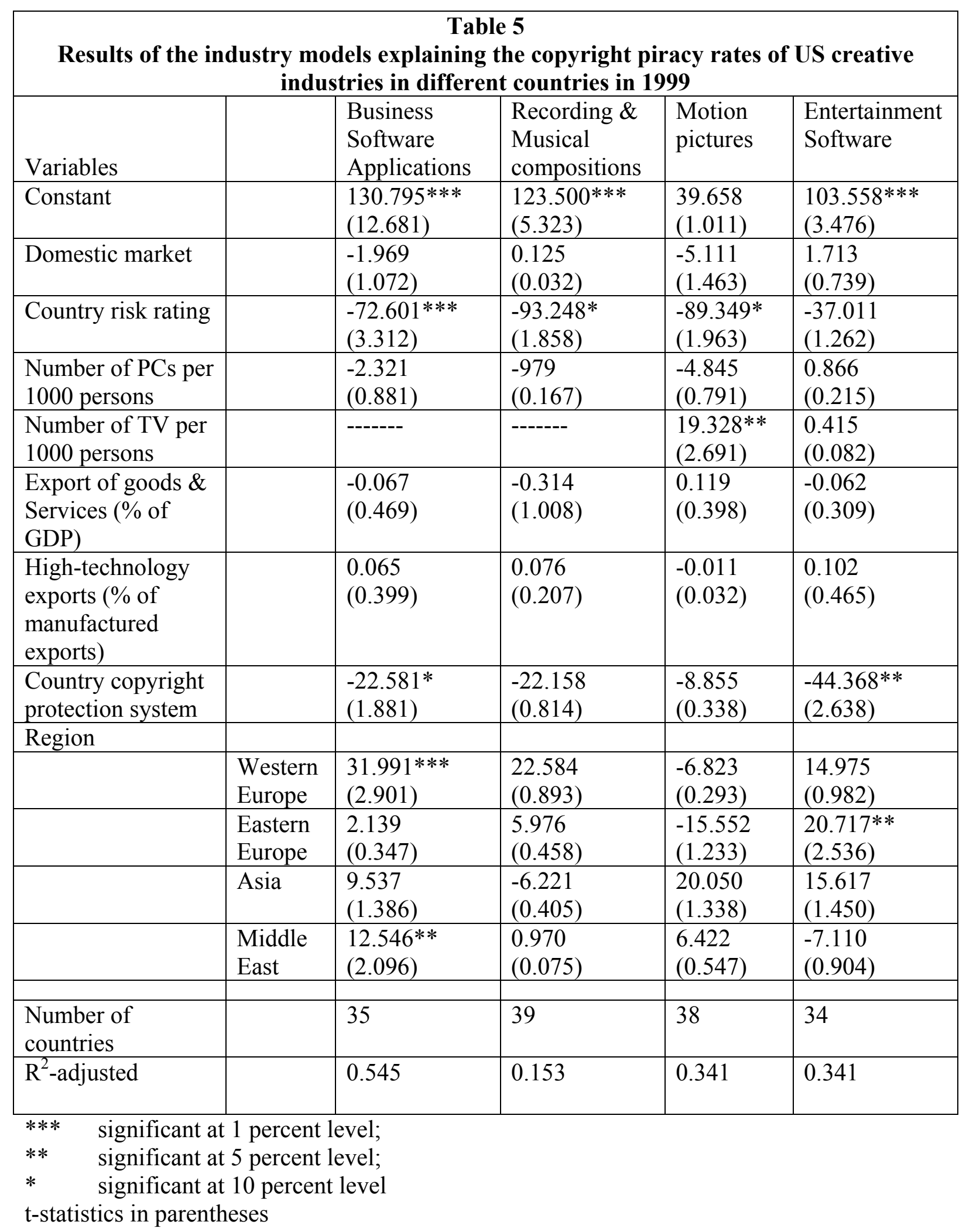




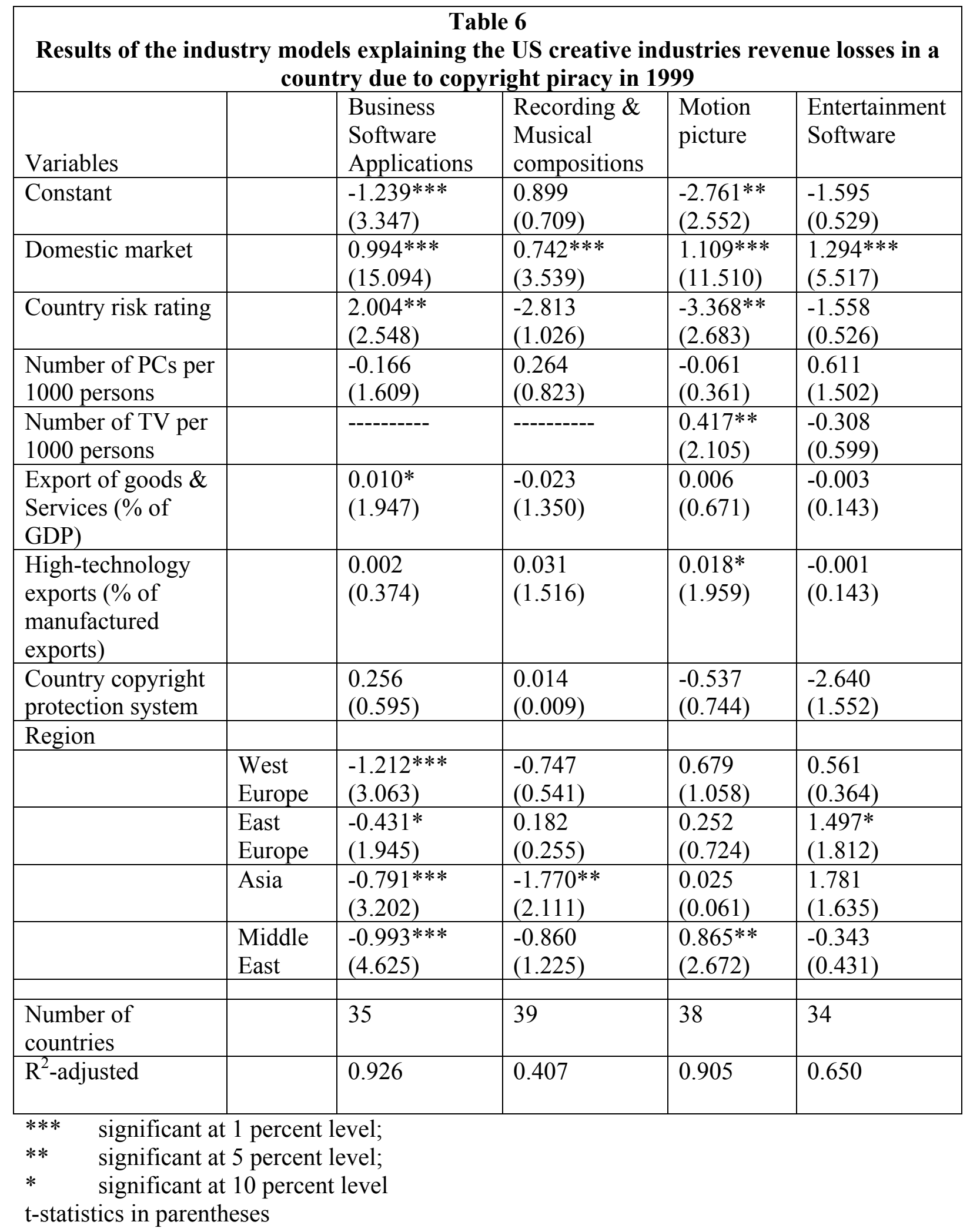




\section{Appendix A}

This appendix describes the estimated piracy rates and associated revenue losses suffered by US copyright-based companies. Data were obtained entirely from archival sources (see also IIPA (1998, 1999, 2000, 2001)).

\section{Business Software Applications}

Data regarding the rates of software piracy and the associated revenue losses were provided by the Business Software Alliance (BSA). The trade group estimates piracy rates by comparing business software applications installed (demand) and business software applications legally shipped (supply). Piracy rates are defined as the volume of software pirated as a percentage of total software installed in each country. The rates are reported as percentages, with $0 \%$ indicating no piracy, and $100 \%$ indicating all business software is pirated. Given the fact that a great deal of software is sold without the computer hardware, it is plausible to assume that the BSA data underestimates the rate of business software piracy. The estimation of revenue dollar losses suffered by the US companies due to piracy of their business software products is calculated by multiplying the shortfall between the actual and the expected sales of software purchased together with a personal computer, by the number of PCs sold, by using the average price per business software application. This is a wholesale price estimate, weighted by the volume of shipments within each software application category. The revenue loss data have to be used with some caution, because the expected sales of software depend on the used method and no price differentiation is included in the model. Despite the limitations, the reported BSA piracy data are one of the most commonly accepted indicators in the industry.

\section{Sound Recording and Musical Compositions}

The national piracy rates and the revenue losses suffered by US companies were calculated by the Recording Industry Association of America (RIAA). This is a trade group that represents the U.S. recording industry. The RIAA bases its estimates on local surveys of the market conditions in each country. The numbers produced by the music industry generally reflect the value of sales of pirated products rather than industry losses. If data is available about piracy recordings that emanate from a third country, this loss data is included in the loss numbers for the country of manufacture, rather than the country of sale. Furthermore, if possible, RIAA employs economic data to project the likely import or sale of legitimate sound recordings, rather than merely reporting pirate sales. In these cases, projected unit displacement is multiplied by the wholesale price of legitimate products in that market rather than the retail price of the pirate products.

\section{Motion Pictures}

The motion pictures industry relies mainly on in-depth knowledge of the particular markets to determine the piracy figures country by country. The nature and impact of piracy in particular markets depends on the level of development of various media in the markets and the different release periods of a product into various media. Since the motion pictures markets are interdependent, piracy in one media form has externalities for other media forms. The total effect of piracy spills over on the revenue losses in other markets depend on the judgment of the professionals in the motion picture industry. To estimate the piracy rates (in percentages) and revenue US dollar losses the industry is divided into three segments: video (encompassing movies provided in video cassette as well as in all optical disc formats); television, cable and satellite; public performance. The data provided by the IIPA are the only data available for this industry.

\section{Entertainment Software}

The US trade association of the entertainment software industry, Interactive Digital Software Association (IDSA), provided the piracy data. Separate estimates of piracy rates pertaining to 
console- and PC-based software are calculated and then averaged into a single piracy rate based on the prevalence of each platform in the market. US companies and other parties related to the entertainment software businesses estimated the individual piracy rates. Piracy rates range from $0 \%$ to $100 \%$. The piracy data are probably biased in favor of the industry. Revenue dollar loss estimates are generated using proprietary methodologies that integrate market data of dedicated platform and PC entertainment software in both compact disc and cartridge formats and hardware shipments. The calculation also took into account the effects of enforcement actions in the countries of production, export and import. Furthermore, it is assumed that pirated entertainment software products in the market displace to some degree legitimate product sales. The displaced sales are multiplied by the wholesale price.

It is important to emphasize that the methodology of piracy figures does not take into account the strategic behavior of companies to encourage piracy. Companies that stimulate piracy of the products should experience lower revenue losses due to unauthorized production and use of their products. 


\section{Endnotes}

${ }^{\mathrm{i}}$ We use estimations of the incurred revenue losses due to piracy provided by the industry associations of the four selected US copyright-based industries. Usually, these associations assume a one-to-one pirate salelegitimate sale relationship. This may result in an overestimation of the actual loss. Pirate products are cheaper and therefore can occupy segments of the market that are not reached with the higher legitimate price. We acknowledge the limitation of the data. However, given that no other data are available, we have decided to use the provided figures for our study.

${ }^{\text {ii }}$ Furthermore, IIPA releases studies on countries that continue to have high levels of piracy that directly affect the U.S. jobs and economic growth.

iii We exclude the creative industry that produces textbooks, professional publications, and journals (both in electronic and print media). The IIPA only publishes the estimated revenue losses due to piracy and not the piracy rates for this industry.

iv Euromoney country risk ratings are based on nine weighted categories that access country risk, covering economic performance, political risk, debt, and access to financial and capital markets. These include economic data $(25 \%)$, political risk $(25 \%)$, debt indicators $(10 \%)$, debt in default or rescheduled $(10 \%)$, credit rating $(10 \%)$, access to bank finance (5\%), access to short-term finance (5\%), and access to capital markets $(5 \%)$. The rates are composed of polls of economists and political analysts supplemented by quantitative data (see e.g. Oetzel, Bettis and Zenner, 2001).

$\mathrm{v}$ Software can be protected against piracy by using copyrights and patents. When software related invention is only a mathematical algorithm, such as a computer program designed to convert binary-coded decimal numbers into binary numbers, then the invention is not eligible patent protection. However, if the invention utilizes the device to manipulate numbers that represent concrete, real world values then the invention is a process relating to those real world concepts and is patentable. However, copyrights are the strongest legal protection instrument to be used in the fight to globally reduce software piracy (Tysver, 2000). 